УдК 621.391

\title{
МЕТОД ФИЛЬТРАЦИИ ИЗОБРАЖЕНИЙ С ИСПОЛЬЗОВАНИЕМ СИНГУЛЯРНОГО РАЗЛОЖЕНИЯ И ТЕХНОЛОГИИ СУРРОГАТНЫХ ДАННЫХ
}

\author{
КОСТЕНКО П. Ю., СЛОБОДЯНЮК В. В., ПЛАХОТЕНКО А. В.
}

Харьковский университет Воздушных Сил,
Украина, Харьков, 61023, ул. Сумская 77/79

\begin{abstract}
Аннотация. В статье предложен метод нелинейной фильтрации аддитивного шума на цифровом изображении, основанный на представлении изображения сингулярным разложением матрицы и применении технологии суррогатных данных к его компонентам. Предложенный метод демонстрирует лучшую пространственную разрешающую способность по сравнению с наиболее распространенными методами оконной фильтрации, что подтверждается результатами имитационного моделирования.
\end{abstract}

Ключевые слова: аддитивный шум; фильтрация; сингулярное разложение; пространственная разрешающая способность; суррогатные данные

\section{ВВЕДЕНИЕ}

Для извлечения полезной информации из изображений в радиолокационных системах дистанционного зондирования, корреляционно-экстремальной радионавигации, медицинской диагностике, биологических исследованиях и в оборонной сфере используются современные вычислительные комплексы, однако последнее слово, как правило, всегда остается за человеком. Эффективность принятия правильных решений оператором дешифровщиком тем выше, чем лучше качество предоставляемой ему информации. Под улучшением качества понимается выполнение комплекса операций, в результате которого изображение становится более пригодным для извлечения полезной информации.

Присутствующие на изображении шумы существенно затрудняют уверенное распознавание объектов и их интерпретацию. Природа образования шумов различна - это аддитивный шум приемного устройства, импульсный шум канала передачи информации, мультипликативный шум, присущий когерентным радиолокационным системам дистанционного зондирования.

Задача подавления шума на изображениях является одной из классических задач обработки изображений.

Для подавления шумов на изображениях в современных программных комплексах используются локальные алгоритмы фильтрации, такие как линейная фильтрация, медианная фильтрация, фильтры Винера. Отличительной особенностью этих алгоритмов является тот факт, что непосредственная обработка изображения ведется в «скользящем окне», размеры которого обычно не превышают $11 \times 11$ пикселей. Это позволяет сделать обработку достаточно быстрой и не требует дополнительной информации о параметрах шума и полезного сигнала. Кроме того, в практике обработки изображений используются методы, основанные на их вейвлет-преобразовании и 


\section{БИБЛИОГРАФИЧЕСКИЙ СПИСОК}

1. Гонсалес Р. Цифровая обработка изображений / Р. Гонсалес, Р. Вудс. - М. : Техносфера, 2005.

2. Фисенко В. T. Компьютерная обработка и распознавание изображений / В. Т. Фисенко, Т. Ю. Фисенко. - СПб. : СПбГУ ИТМО, 2008.

3. Грузман И. С. Цифровая обработка изображений в информационных системах / И. С. Грузман, В. С. Киричук. - Новосибирск : НГТУ, 2002.

4. Виткус Р. Ю. Адаптивные линейные фильтры для обработки изображений / Р. Ю. Виткус, Л. П. Ярославский : под ред. В. И. Сифорова, Л. П. Ярославского // Адаптивные методы обработки изображений. М. : Наука, 1988. - С. 6-35.

5. Солодушкин В. И. Оптимальная по разрешающей способности фильтрация изображений / В. И. Солодушкин, В. А. Удод // Оптика атмосферы. - 1991. — Т. 4, № 10. - С. 1030-1034.

6. Родионов C. А. Оценка качества оптического изображения / С. А. Родионов // Справочник одномерная вычислительная оптика. - Л.: Машиностроение, 1984. - С. 268-282.

7. Ширман Я. Д. Разрешение и сжатие сигналов / Я. Д. Ширман. - М. : Сов. радио, 1974.

8. Костенко П. Ю. Уменьшение аддитивного шума на цифровых изображениях с использованием технологии суррогатных данных / П. Ю. Костенко, 
В. И. Василишин, В. В. Слободянюк / Системи обробки інформації. - 2014. - № 8. - С. 33-38.

9. Kantz H. Nonlinear time series analysis / H. Kantz, T. Schreiber. - Cambridge : University Press, 2004.

10. Small M. Applied Nonlinear Time Series Analysis Applications in Physics, Physiology and Finance / M. Small. - World Scientific Publishing Co. Pte. Ltd., 2005.

11. Эфрон Б. Нетрадиционные методы многомерного статистического анализа / Б. Эфрон : пер. с англ. — М. : Финансы и статистика, 1988.

12. Костенко П. Ю. Использование суррогатных сигналов для повышения качества оценки параметров регулярных и хаотических сигналов, наблюдаемых на фоне аддитивного шума / П. Ю. Костенко, К. С. Васюта， В.В.Слободянюк， Д. С. Яковенко // Системи управління, навігації та зв’язку. — 2010. — № 4. — С. $28-32$.

13. Костенко П. Ю. Коррекция обработки сигналов при их спектральном анализе с использованием суррогатных автоковариационных функций наблюдения, полученных ATS-алгоритмом / П. Ю. Костенко, В. И. Василишин // Радиоэлектроника. - 2014. - Т. 57, № 6. - С. 3-12. - (Известия вузов). - Режим дос-

Поступила в редакцию 30.07.2015 тупа

http://radio.kpi.ua/article/view/S0021347014060016.

14. Костенко П. Ю. Повышение эффективности спектрального анализа сигналов методом Root-MUSIC с использованием суррогатных данных / П. Ю. Костенко, В. И. Василишин // Радиоэлектроника. - 2014. - Т. 57, № 1. - С. 31-39. — Режим доступа : http://radio.kpi.ua/article/view/S0021347014010026.

15. Слободянюк B. В. Анализ влияния вида развертки зашумленного цифрового изображения на эффективность метода подавления шума, использующего технологию суррогатных данных / В. В. Слободянюк, О. В. Шаповалов / Системи обробки інформації. - 2015. - № 5. - С. 22-27.

16. Данилов Д. Л. Главные компоненты временных рядов : Метод “Гусеница" / Д. Л. Данилов, А. А. Жиглявский. - СПб. : СПбГУ, 1997. - 308 с.

17. Gershman A. B. Improved DOA estimation via pseudorandom resampling of spatial spectrum / A. B. Gershman, Johann F. Bohme // IEEE Signal Process. Lett. - Feb. 1997. - Vol. 4, No. 2. - P. 54-57. - DOI : $\underline{10.1109 / 97.554472 .}$ 